\title{
Fertility-Sparing Surgery In Early Stage Cervical Cancer
}

\author{
IN Gede Budiana', Tjokorda Gede Astawa Pemayun ${ }^{2}$ \\ ${ }^{1}$ Gynaecologic oncology consultant, ${ }^{2}$ Obstetris \& Gynaecology resident \\ Obstetrics \& Gynaecology department, Udayana University/Sanglah, General Hospital Bali
}

\section{ARTICLE INFO}

\section{Article history}

Received 11 January 2018

Received in revised form 31 January 2018

Accepted 5 April 2018

\section{Keywords:}

Cervical Cancer; early-stage;

Conservative Surgery; Conization;

Trachelectomy.

\section{Kata Kunci:}

Kanker Serviks; Stadium Awal; Bedah Konservatf; Konisasi; Trakelektomi.

\begin{abstract}
Cervical cancer is a malignancy in women that cause major impacts, not only biologically, but also in various aspects of life. On patients during reproductive age, cervical cancer poses severe sexual and reproductive debilitation. Trend in the onset of first diagnosis is moving towards younger age, and mostly affect women in their reproductive age. This would give a bad impact on the sustainability of the patient's reproductive function. Until now, fertilitysparing approach for the management of early-stage cervical cancer is still rare in Indonesia. However, some options of conservative surgical therapy are available for patients who desire fertility, namely conization, simple tracellectomy, radical trachelectomy, and also neoadjuvant chemotherapy. These options have been proven effective and safe, while maintaining patients' reproductive functions.
\end{abstract}

\section{ABSTRAK}

Kanker serviks merupakan suatu penyakit keganasan pada wanita yang memiliki dampak luas, tidak hanya pada tubuh penderita, namun juga berbagai aspek kehidupan penderita. Pada penderita di usia reproduktif, kanker serviks menimbulkan masalah seksual dan reproduksi yang berat bagi penderita. Kini usia dimana terjadinya kanker serviks mulai menunjukkan kecenderungan yang semakin muda yang tentunya memberikan dampak buruk terhadap keberlangsungan fungsi reproduksi pasien. Hingga saat ini, tatalaksana kanker serviks stadium awal dengan pendekatan fertility-sparing masih jarang dilakukan di Indonesia. Namun, beberapa pilihan terapi bedah konservatif tersedia bagi pasien yang menginginkan fertilitas, yakni konisasi, trakelektomi sederhana, trakelektomi radikal. hingga pemberian kemoterapi neo-adjuvant. Pilihan terapi ini telah terbukti efektif dan aman, serta mampu mempertahankan fungsi reproduksi pasien.

\section{PENDAHULUAN}

Cervical cancer is a cancer affecting women and causing 275,000 deaths that ranks second in the world in terms of total incident and mortality rates,.$^{1}$ In America, cervical cancer ranked third amongst gynecologic cancers, with 12,990 new cases, and 4,120 deaths in 2016. ${ }^{2}$ A national survey in Indonesia shows 20,928 new cases per year and was the most common gynaecologic cancer in 2012. ${ }^{3}$ Nowadays, the age of the patient at the time of diagnosis tends to be younger. The World Health Organization (WHO) states that in Indonesia most cervical cancers are diagnosed at the age of 15-44 years, which is the reproductive age. ${ }^{3}$ Low income and low educational level are significant risk factors. ${ }^{4}$ It is thought that early detection programs serve a major role. Approximately $59 \%$ of patients younger than 30 are diagnosed by screening, and $61 \%$ of these are found in the first screening. ${ }^{5}$ In the UK by 2016 , there is

* Corresponding author: IN Gede Budiana Departement of Obstetrics \& Gynaecology, Udayana University/ Sanglah, General Hospital Bali email: budiana1971@gmail.com; tjokgedeap@gmail.com 
an estimated $95 \%$ decrease in the incidence of stage III cervical cancer and above after the implementation of periodic screening programs. ${ }^{6}$ This poses a new problem, as about $40 \%$ of patients with early-stage cervical cancer that are diagnosed at reproductive age, have strong desire to maintain fertility. ${ }^{7}$ Along with the improving economy, childbearing age women in large cities tend to become pregnant at an older age. Thus, more women will be diagnosed with cervical cancer before ever having children. ${ }^{7,8}$ Therefore, various treatment options have been developed for early-stage cervical cancer patients, who still want to maintain fertility, without reducing survival rate.

Until recently, the principle of cervical cancer therapy is similar for all stages, i.e. surgery or radiation for primary tumors, and adjuvant therapy for metastatic potential. ${ }^{8,9}$ In early-stage cervical cancer, several surgical options are available namely conization, simple trachelectomy and radical trachelectomy combined with pelvic lymphadenectomy. ${ }^{10-13}$ The survival and recurrence rates of the treatments depend on the stage at diagnosis, histologic type, lympho-vascular space invasion, and the tumor free margin. ${ }^{14}$ In general, these existing conservative surgical options have shown promising results. ${ }^{15,16}$

\section{Early-Stage Cervical Cancer}

The term microcarsinoma of uterine cervix was first proposed by Mestwerdt (1947). In 1974, the Society of Gynecologic Oncologists (SGO) proposed a term of microinvasive carcinoma that included lesions involving basement membranes to a depth of $3 \mathrm{~mm}$ or less, without evidence of lymphovascular space involvement (LVSI). It was not until 1995 that the International Federation of Gynecology and Obstetrics (FIGO) adopted the term microinvasive-stage into stage IA1 and IA2, but LVSI was not a determinant. ${ }^{9}$ Nowadays, most literatures use the term early cervical cancer to describe tumors that are confined in the cervix, measuring $\leq 4 \mathrm{~cm}$, in the absence of any apparent evidence of metastasis in surrounding structures and distant organs (stage IA1 IB1). ${ }^{11}$

\section{Epidemiology}

Globally, it is estimated that 530,000 new cases and 275,000 deaths occur in $2008 .{ }^{9}$ In 2016, 12,990 new cases and 4,120 deaths from cervical cancer were reported in the United States. ${ }^{2}$ Cervical cancer is the most common cancer in Africa, East Asia, South Asia, and
Melanesian countries. ${ }^{9}$ Incidence of cervical cancer in Southeast Asia reaches 16.6 per 100,000 women, in which Indonesia ranks fourth with a rate of 17 per $100,000 .^{3}$ In 2012 a research in Indonesia showed that cervical cancer is the most common gynecologic cancer, with 20,928 new cases per year. ${ }^{3}$ In most less-developed countries as in Africa, about $95 \%$ of cervical cancer cases are detected at an advanced stage. ${ }^{17}$

In more developed countries, the incidence of cervical cancer begins to show changes at the age and stage of diagnosis, due to various methods of early detection. In the United States, about $56.45 \%$ invasive cancers have been diagnosed at a local stage in the last 35 years. ${ }^{18}$ Similarly in Ireland, 55\% patients are diagnosed in stage I. ${ }^{19}$ Cervical cancer is the third most common cancer in women younger than 40 , of which about $42 \%$ of all cases are diagnosed before age 45 , and about $40 \%$ of earlystage cervical cancer patients are young women who want to maintain fertility. In the United Kingdom, the number of new cases with age less than 25 years tripled within the last decade. ${ }^{7}$

\section{History Of Fertility-Sparing Surgery}

Lymph nodes involvement has been recognized to be a major risk factor for recurrence and metastasis in cervical cancer, in addition to histologic types, depth of invasion, and tumor size. ${ }^{20,21}$ Since the introduction of microinvasive carcinoma, studies have sought to relate postoperative findings and patient's prognosis. It was reported that malignant cells in the lymph node were found in less than $1 \%$ of stage IA1 squamous carcinoma patients, as well as rare LVSI number which is directly proportional to the depth of invasion. In cases of stage IA1 and IA2 adenocarcinoma undergoing pelvic lymphadenectomy, only in $1.5 \%$ cases that malignant cells were found in the lymph nodes, and 3\% was LVSI positive. The overall prognosis of the patient is good in early-stage cervical cancer. This raises the notion that less radical and fertility-sparing options may be considered for this group. ${ }^{9}$

In 2006, the American Society of Clinical Oncology (ASCO) issued recommendations on the importance of assessing fertility issues when dealing with cancer patients at reproductive age. ${ }^{11,22}$ In the past, conservative surgical method may only be applied to FIGO stage IA1 cervical cancer, while in stage IA2 and above, radical hysterectomy and pelvic lymphadenectomy or radiation therapy will be issued. ${ }^{8}$ 
In 1994 at the annual SGO meeting, Daniel Dargent and colleagues presented an eight-year experience on vaginal radical trachelectomy (VRT) combined with laparoscopic pelvic lymphadenectomy as a fertilitysparing surgery for early-stage cervical cancer, subsequently known as Dargent surgery. Abdominal radical trachelectomy (ART) is another approach firstly introduced by Eugen Aburel in 1932. It was not until 1997 that this technique was again introduced by Del Priore and Smith, who implemented paraservical tissue resection as close as Piver type III extended hysterectomy. ${ }^{8,23}$

Recent trend leads to a less radical approach in 2007, which was introduced by Rob et al. Such action is laparoscopic pelvic lymphadenectomy with or without sentinel node mapping, followed by simple trachelectomy or conization when no malignant cells are present in the lymph nodes. ${ }^{24,25}$

\section{Patient's Eligibiity}

It has been reported that about $48 \%$ of women with early-stage cervical cancer undergoing radical hysterectomy fulfill the criteria for conservative surgery. ${ }^{22}$ However, before deciding on a conservative option, there are certain indications and conditions that have to be met. The general criteria for conservative surgery can be seen in Table 1. The main histopathologic criteria that should be evaluated are regional lymph node involvement, tumor size, and histologic type. LVSI status and depth of stromal invasion are not contraindication, but are considered as risk factors for recurrence in various studies. ${ }^{14}$

Tumor size of less than $2 \mathrm{~cm}$ is the best candidate for conservative surgery (FIGO stage IA1 - IB1)..$^{8}$ In cases with the largest tumor diameter of $\leq 2 \mathrm{~cm}$, superficial stromal invasion, and negative LVSI, the parametric and lymph node invasions were only $1 \%$ and $2.4 \%$ respectively. ${ }^{21}$ Whereas in small tumors and negative lymph node metastasis, the parametric involvement was only found as much as $0.6 \%{ }^{26}$ Tumors measuring $\leq 2 \mathrm{~cm}$ were also reported to have a good prognosis. ${ }^{27}$ The size of tumor can be measured by direct physical examination, colposcopy, or magnetic resonance imaging (MRI). ${ }^{26,28}$ Yamazaki et al suggested the use of conservative therapy in tumors less than $25 \mathrm{~mm}$ in size and volume less than $5.000 \mathrm{~mm}^{3}$ on MRI examination. ${ }^{28}$ Tumors larger than 2 $\mathrm{cm}$ had a greater risk of extrauterine spread and a higher recurrence rate than tumor-sized less than $2 \mathrm{~cm}(20.8 \%$ vs $2.9 \%$ on VRT, and $18.2 \%$ vs. $1.6 \%$ in ART). ${ }^{8}$
Table 1. General criteria of fertility-sparing surgery

\section{Patient Criteria}

- Astrong desire to maintain pregnancy

- Reproductive age with good pregnancy opportunities $(<40-45$ years)

- Have received and understood information about the available options and the selected therapy

\section{Tumor Criteria}

- Tumors confined to the cervix ( $\leq 4 \mathrm{~cm}$ in largest diameter), preferably in tumors confined to ectocervix

- Minimal endocervical involvement, proven through colposcopy and/or MRI examination

- Small-cell neuroendocrine histologic type is the exclusion criterion

- There is no evidence of lymph node involvement and/or distant metastases

\section{Facility Criteria}

- Have good standards and quality control on the implementation of conservative surgical therapy

- Experienced operators

* Women with tumors larger than $4 \mathrm{~cm}$ are potential candidates for adjuvant chemotherapy.

Histologic type is also said to affect the clinical outcome, but has not shown consistent results. In recent decades, adenocarcinoma and adenosquamous carcinoma incidences have increased in comparison with squamous carcinoma, especially in younger age populations..$^{29}$ Several studies have reported higher recurrence and lower survival rates in adenocarcinoma, while other studies found no significant difference in disease-free time. ${ }^{29,30}$ Therefore, it is considered rational to apply a similar approach between the three histologic types. ${ }^{9}$ Endometrioid carcinomas often appear at the proximal endocervical canal, and are associated with long-term recurrence and poor survival rates in early-stage cervical cancer. ${ }^{9,31}$ Smallcell neuroendocrine tumors should not be included, because the prognosis is worse compared to others. ${ }^{8}$

\section{SURGICAL OPTIONS Conization}

The first description of a funnel amputation of uterine cervix or now referred to as conization, was reported by Sturmdorf in 1916. At that time this technique had a considerable risk of bleeding, and hemostasis was 
performed by mucosal flap suture over excision. Until then in 1954, Thornton et al suggested lateral cervical sutures for hemostasis. This technique subsequently experienced various developments by clinicians, such as the use of electroconization by Hahn (1948) and the freeze conization by Sherif (1963). ${ }^{32}$

Currently there are two commonly used conization techniques which are loop electrocauterization excisional procedure (LEEP) and cold knife conization (CKC). Both of these techniques have been suggested by the WHO panel of experts as the preferred therapy for precancerous lesions. ${ }^{33}$ Cold knife conization provides accurate excision and allows for better histologic evaluation including tumor margin evaluation however it is associated with greater surgical haemorrhage. While LEEP is technically easier, less time consuming, and less bleeding, it may cause electrocauter artifacts that makes histopathologic evaluation of tumor margin difficult. ${ }^{34,35}$

It was reported in various literatures that in earlystage cervical cancer patients, who undergo diagnostic conization and then treated with trachelectomy, showed no cancer residue in cervical specimens in about 40-65\% of the cases. ${ }^{24}$ From all early-stage cervical cancer patients undergoing radical hysterectomy, it is estimated that $26 \%$ are good candidates for conservative surgery. ${ }^{36}$ Various studies have reported very low lymph node involvement in FIGO stage IA, which is only about $1.5 \%$. In fact, in stage IA cervical cancer with stromal invasion depth of $\leq 5 \mathrm{~mm}$, no lymph node involvement was found. ${ }^{27}$

In patients with early-stage cervical carcinoma, especially in stage IA 1 and IA2, parametrial involvement was reportedly low. ${ }^{38,39}$ It was reported that from all early-stage cancers, approximately $7.7 \%$ had parametrial involvement. However, when it includes only patients with low risk characteristics (adenosquamous, squamous cell carcinoma and adenocarcinoma histology, tumor size $<2 \mathrm{~cm}$ without LVSI), no parametrial involvement was found in the sample. ${ }^{26}$ Other study reported that parametrical involvement was only about $0.6 \%$ in patients with tumor size $<2 \mathrm{~cm}$, negative lymph node, and depth of invasion $\leq 10 \mathrm{~mm} .{ }^{24}$

Lymphovascular space involvement is rare in stage IA1, and its presence does not affect FIGO stage, though it is said to be a risk factor for recurrence. ${ }^{9,40}$ To date, the impact of LVSI on the prognosis of micorinvasive carcinomas is controversial. ${ }^{9}$ In some centers, patients with stage IA1 cancer that show positive LVSI from diagnostic conization, definitive conization is carried out preceded by lymphadenectomy; nodal involvement is confirmed with frozen section. ${ }^{27,41}$ Conization must ensure that the cervical specimen margin is free from invasive or preinvasive cancer lesions. If the first conization cannot achieve tumor free margin, then reconization must follow. ${ }^{9,27}$ However, Lee et al reported that there is no relationship between LVSI status with pathology examination results, as well as between tumor margin status and follow-up results. Thus, conization is considered safe and effective for stage IA1 carcinoma, regardless of tumor margin status and LVSI. ${ }^{9,42}$ Conization in adenocarcinoma is controversial due to the difficult diagnosis of microinvasion in this type. ${ }^{10}$ However, most authors suggest that adenocarcinoma and squamous carcinoma are treated the same at stage IA1.9,10,43

Conization can also be considered in stage IA2 and IB1 cervical cancers with low risk characteristics (tumor $<2 \mathrm{~cm}$, age $<45$ years, low risk histology). One study involving 36 stage IB1 cervical cancer patients aged $24-40$ years old who were treated with conization or re-conization (due to lack of tumor free margin), only one patient had a recurrence after 34 months post-therapy. ${ }^{26}$ To reduce the risk of recurrence, conization may be preceded by laparoscopic lymphadenectomy. In a group of patients undergoing pelvic lymphadenectomy, the parametrial involvement rate was only $0.4 \%$ in patients with negative lymph node involvement. ${ }^{26}$ If frozen section result shows no nodal metastasis, wide conization may be performed. ${ }^{24,26}$ There are several factors that may increase the risk of occurrence such as older age, postmenopause, presence of clinical symptoms and invasive carcinoa at specimen margin or endocervical involvement. ${ }^{44}$ However, the risk of residual disease and repeat surgery is low in patients with stage IA1disease. ${ }^{45}$

In general, conization is an adequate therapy for stage IA1 and the prognosis is good. In a study by Andikyan et al (2014) they reported no recurrencewithin 17 months post-conization. ${ }^{47}$ Bisseling et al reported no recurrence within 72 months post-conization in 29 patients with stage IA1 and IA2. The study by Tseng et al obtained $100 \%$ survival rate within 6.7 -year post-conization. ${ }^{48}$ Wright et al studied 1.409 patients and reported that the 5 -year survival rate was similar between patients with stage IA1 undergoing hysterectomy and conization (99\% vs $98 \%$ ). In patients with stage IA2 squamous type, no death was found during 18-year post-conization period. ${ }^{49}$ Research by Fagotti et al in stage IA2 or IB1 patients showed no recurrence in the mean 16-month period. ${ }^{49}$ When compared to hysterectomy, adenocarcinoma stage IA2 patients who underwent conization had similar 5-year survival rate. However, in the squamous histologic type, hysterectomy provides slightly better survival $(96.3 \%$ vs. $90.2 \%) .{ }^{49}$ 


\section{Simple Trachelectomy}

In stage IA2 and IB1, radical trachelectomy is the treatment of choice in terms of conservative approach. It provides good fertility outcomes, but not as good as conization, and is also associated with morbidity from parametrectomy. ${ }^{10,49}$ Therefore, questions about the need for radicality in trachelectomy arises, supprted by studies showing that the parametrial involvement is very low in some groups. $8,49,50$

Various studies show that the parametrial involvement is ver low (less than $1 \%$ ) in patients with tumor sized $\leq 2$ $\mathrm{cm}$, in the absence of deep stromal (> $10 \mathrm{~mm}$ ) invasion, LVSI, and lymph node maetastasis. ${ }^{49}$ Generally, in earlystage patients with low risk characteristics, parametrial involvement is only less than $1 \%(0-0.6 \%) .{ }^{10.50}$ Volumetry with $\mathrm{MRI}$ can estimate tumor size and volume. ${ }^{28,51} \mathrm{MRI}$ can also be used to estimate the range of stromal infiltration and extent of unaffected stroma. ${ }^{8}$ Most authors suggest simple trachelectomy for those with low-risk histologic types (adenosquamous, adenocarcinoma, and squamous). In patients with high-risk histology (sarcoma, neuroendocrine, and serous), the impact of lower radicality on patient's prognosis is not well established. ${ }^{49-52}$

Positron emission tomography/computed tomography (PET-CT) scans can be used for lymph nodes evaluation preoperatively. ${ }^{8}$ Compared to MRI, PET-CT scans have better sensitivity and specificity (75\% vs $56 \%$; $98 \%$ vs. $93 \%) .{ }^{10}$ Simple trachelectomy combined with pelvic lymphadenectomy is preferred for stage IA2 and IB1, especially in cases with negative LVSI and tumor mass $\leq 2 \mathrm{~cm} .{ }^{9,50}$ The action should be preceded by pelvic lymphadenectomy to exclude lymph node involvement. However, the number of stage IA2 patients is low, making it difficult in conducting a large prospective study. ${ }^{9}$ In a study by Plante et al involving 12 patients with stage IA1 to IB1 with adenocarcinoma and squamous types, no recurrence was found in all patients within the mean 27 months. The 24-months disease-free period is $100 \%$ in the study. ${ }^{52}$ Generaly, the risk of surgery is similar to that of VRT, ie bleeding, urinary tract injury, intestinal injury, urinary and defecation disorders..$^{53}$

\section{Radical Trachelectomy}

Radical tracellectomy may be performed through laparotomy (or commonly called abdominal radical trachelectomy, ART), vaginal (VRT), laparoscopic (LRT) or robotic (RRT). ${ }^{54-56}$ In 1952 Novak introduced a less radical method for women with carcinoma in situ, in order to maintain fertility. This includes radical lymphadenectomy, radical cervical and upper vagina extirpation, along with paracervical and paravaginal tissue, through laparotomy access. This action was then performed on invasive cervical cancer patient by Aburel in 1957, which was then introduced as a subfundus radical hysterectomy. ${ }^{57}$ In 1977, Burghrdt and Holzer explained that removal of the uterine fundus and adnexae are not required in the management of small sized cervical cancer. This technique is increasingly known to the world after popularized again by Dargent through vaginal approach. ${ }^{58}$

Radical trachelectomy is a good choice for stage IA1, IA2 LVSI positive, and stage IB1. The involvement of regional lymph nodes should be confirmed before action is decided. ${ }^{55,56}$ Some characteristics that show good prognosis are tumor size of $\leq 2 \mathrm{~cm}$, confined to cervix, infiltration depth $<10 \mathrm{~mm}$, and LVSI negative. Although LVSI is not a good prognostic factor, its significance is not well established and is not an absolute contraindication. ${ }^{10}$ Positive LVSI are found in 30\% ART and 30.1\% VRT patients. ${ }^{8}$ The number of lymph nodes involvement and LVSI positive in patients with stage IA1-IB1 are 16-27\% and $39 \%-41 \%$ respectively. ${ }^{57}$ Small-cell carcinoma, sarcoma and neuroendocrine tumors are not recommended for this procedure because of the high potential of lymph node metastasis, LVSI, and distant metastasis. ${ }^{10,57}$ Although adenocarcinoma is associated with more endocervical involvement, studies showed similar outcomes when compared to squamous carcinoma, and should be treated in the same fashion. ${ }^{10}$

Most experts agree that radical trachelectomy should be limited to patients with tumor size $\leq 2 \mathrm{~cm}$, with similar outcomes in both vaginal and abdominal approaches. Overall, the recurrence rate was 3-6\% with $2-5 \%$ mortality. ${ }^{9}$ The outcome of tumors sized $>2 \mathrm{~cm}$ is not satisfactory. ${ }^{9}$ The recurrence rate was $19 \%$ in tumors measuring $>2 \mathrm{~cm}$, and $25 \%$ in tumors sized $>2 \mathrm{~cm}$ with a depth of invasion $>10 \mathrm{~mm} .{ }^{10}$ In patients with stage IB1 sized $>2 \mathrm{~cm}$, ART is more prefered to VRT due to higher recurrence rate in vaginal access. ${ }^{14}$

Table 2. Good candidates for radical trachelectomy

1. Invasive carcinoma with squamous, adenocarcinoma or adenosquamous histology

2. FIGO stage IA1 LVSI positive, FIGO IA2 L0 or L1V0, up to IB1 LO or L1VO

3. Strong desire to maintain fertility

4. Tumor size $\leq 4 \mathrm{~cm}$

5. Limited endocervical involvement (mass resection allows free margin $\geq 5 \mathrm{~mm}$ )

6. Estimated cervical remnant $\geq 1 \mathrm{~cm}$

7. If previously surgically confirmed (conization), the acute inflammatory phase must have been passed (usually 6 weeks post conization)

8. Negative lymph node involvement 
Patients with stage IA2 and IB1 cervical cancers have a high incidence of lymph node metastasis, thus, preoperative lymph node examination should be performed, either laparoscopically or abdominalally. Dissection is performed on the internal and external iliac lymph nodes, as well as the obturator, which is then examined for frozen section. If no lymph node involvement is detected, radical trachelectomy may be performed. If nodal involvement is positive, radical hysterectomy should be the treatment of choice. ${ }^{10}$ Examination of sentinel lymph node to estimate regional lymph node involvement is also workable, with $91 \%$ and $100 \%$ sensitivity and specificity. ${ }^{10}$ Uterine cervix amputation is done as high as 7-10 $\mathrm{mm}$ above the lesion. ${ }^{12}$

Two stage frozen section is recommended: lymph nodes examination (to determine regional metastases) and on cervical specimen (to determine tumor-free margin). ${ }^{8}$ However, histopathologic examination to determine tumor-free margin is not always easy, especially in adenocarcinoma. Many centers apply macroscopic evaluation of tumor boundary, and take action based on these rough estimates, without doing frozen section of the cervix. ${ }^{8}$

The important thing before deciding conservative therapy for stage IB1 patients is determining the extension of tumor pre-operatively. Physical examination and colposcopy are mandatory. ${ }^{55} \mathrm{MRI}$ is reported to provide satisfactory results in estimating the size and depth of tumor invasion, compared with CT scan or physical examination alone. ${ }^{9,10}$ Lymph node involvement can be estimated with PET-scan. ${ }^{55}$

The radicality of the cervical and parametrial excision should be adjusted accordingly, such as in type B or C type radical hysterectomy, with or without nerve-sparing. Classic ART involves resection of the uterine arteries to its base. However, modification without total resection of uterine artery has been presented. The uterine and vaginal sutures and also the formation of neocervix are different in each center. ${ }^{8}$ Abdominal trachelectomy is preferred in cases with distorted cervicovaginal anatomy, nulliparas, and when extensive parametrial resection is necessary. This technique also is more familiar for most gynecologists. ${ }^{10}$ Laparoscopic techniques provide benefits similar to ART and lower complications such as seen in the vaginal approach. ${ }^{10}$ Robotic technology provides even better accuracy and coverage. ${ }^{10}$

Meta-analysis by $\mathrm{Xu}$ et al found that between radical trachelectomy and radical hysterectomy in stage I-II patients, there was no significant differences in recurrence rates, 5-year survival rates, post operative mortality, intraoperative complications, postoperative complications, and transfusion needs. ${ }^{15}$ Radical vaginal trachelectomy is particularly preferred in terms of reducing the average bleeding, time required to normal urine residue, and hospitalization time. ${ }^{10,15}$

Meta-analysis by Bentivegna et al reported recurrence rates in various radical trachelectomy approaches: vaginal/Dargent procedures (4.2\%), laparotomy (4.6\%), laparoscopic $(6.3 \%)$, and robotic (2.2\%). Wethington et al reported $4 \%$ recurrence rate after ART. ${ }^{16}$ Intraoperative complications occur in about $4 \%$ cases, including gastrointestinal, bladder, ureter, and blood vessel injury. ${ }^{13}$ There are several morbidities or complaints associated with radical trachelectomy including dysmenorrhea (24\%), dysplastic pap smear (24\%), irregular menstruation (17\%), recurrent candidiasis (14\%), cervical suture problem (14\%), cervical stenosis $(10 \%)$, prolonged amenorrhea (10\%), and sometimes dyspareunia. ${ }^{9,12}$ Cervical stenosis is associated with the use of cervical cerclage methods, and the prevention of stenosis, such as the use of intrauterine cannulas. ${ }^{60}$

Laparoscopic and robotic radical trachelectomy are the future of conservative surgical techniques, but the lack of research on this approaches make it difficult to determine its current safety and effectiveness. Kim et al reported that in 32 patients with an average $1.7 \mathrm{~cm}$ tumor size treated with LRT, the mean operative time was 290 minutes (120-520 minutes), loss of blood 332 $\mathrm{ml}$ (50-1000 $\mathrm{ml})$, and no recurrence or death after 31 months follow-up. ${ }^{61}$ Billard et al reported similar results in terms of intraoperative complications of LRT: average operative time of $240 \mathrm{~min}$ and $100 \mathrm{ml}$ blood loss. ${ }^{62}$ With robotic techniques, blood loss even reached $<100 \mathrm{ml}$, as reported by Nick et al. ${ }^{63}$

Current indications for radical trachelectomy are developed for tumors measuring $\geq 2 \mathrm{~cm}$. In 35 patients undergoing ART, no recurrence was observed in a 30-month follow-up period. ${ }^{64}$ Retrospective study by Wethington et al reported that from 29 stage IB1 patients with tumors measuring $2-4 \mathrm{~cm}$ undergoing ART, there was only one recurrence within 44 months period. ${ }^{65}$ Lintner et al reported a 5-year survival rate after ART in patients with tumors larger than $2 \mathrm{~cm}$ was about $93.5 \% .{ }^{66}$ It was said that abdominal access is better than vaginal. In stage IB1 stage measuring $>2 \mathrm{~cm}$, relapse was found in $17 \%$ of patients undergoing VRT, and $7 \%$ of those undergoing ART. ${ }^{14}$

\section{Neo-Adjuvant Chemotherapy}

The role of conservative surgical therapy is limited in cases with large tumor size $(>2 \mathrm{~cm})$ and deep stromal invasion (> $10 \mathrm{~mm}$ ). The use of neoadjuvant chemotherapy (NAC) is now proposed for tumor mass reduction so that conservative surgery can still be done. This approach was 
first introduced by the Maneo group presented at the 2004 International Gynecologic Cancer Society (IGCS) meeting. In that study, the patients underwent three cycles of chemotherapy, followed by pelvic lymphadenectomy and CKC. ${ }^{8}$ Plante et al applied laparoscopic pelvic lymphadenectomy followed by VRT after previously given NAC. ${ }^{8}$ The relapse rates are generally reported as low as $6-7.6 \%{ }^{14,67}$

Research by Buenerd and colleagues performing VRT in 7 women who had received NAC (paclitaxel $175 \mathrm{mg} /$ $\mathrm{m} 2$, ifosfamid 5,000 mg / m2, cisplatin $75 \mathrm{mg} / \mathrm{m} 2$ ) found no recurrence within 22 months. ${ }^{68}$ Aside from trachelectomy, NAC can also be combined with conization or wide conization, depending on the tumor's response to chemotherapy. ${ }^{69,70}$ It has been reported that $80 \%$ of women undergoing post-NAC conization showed no malignant cell residue on pathology examination. ${ }^{70}$

The results of these studies can be a sign that conservative surgical techniques may be implemented even up to stage IIA1 disease. ${ }^{68}$ However, NAC administration should be considered in patients with normal ovarian function, given the adverse effects of chemotherapy on ovarian function. This down-staging action is still in the stage of multicenter research to determine the effectiveness and safety of the action. ${ }^{12}$

\section{Fertility And Obstetrics Outcomes}

The rate of pregnancy with radical trachelectomy is generally estimated to be $41-70 \%$, and failure is largely related to cervical stenosis, lack of cervical mucus, or tubal disorders. More than 300 pregnancies with a live birth rate of $68 \%$ is reported. Compared to the general population, the second-trimester pregnancy failure rate associated with premature contractions and premature rupture of the membranes is higher in radical trachelectomy. ${ }^{13}$ Delivery before 32 weeks occurs in $10 \%$ of pregnancies, and preterm delivery occurs in $22 \%$ of pregnancies. ${ }^{13}$ Resection of the uterine artery is more common in abdominal trachelectomy rather than VRT, and is thought to be the cause of adverse fertility outcomes and the ability to sustain pregnancy until term. However, this still needs to be proven. ${ }^{13}$

The latest meta-analysis by Bentivegna et al found that pregnancy rates ranged from $48-81 \%$ in various conservative surgical techniques, with details: laparoscopic radical trachelectomy (48\%), laparotomy radical trachelectomy (49\%), simple trachelectomy or conization (57\%), vaginal radical trachelectomy/ Dargent procedure (63\%), NAC (69\%), and robotic radical trachelectomy (81\%). ${ }^{14}$

Neither of non-radical (simple conization or trachelectomy) and radical techniques harbors the risk of preterm delivery in pregnancy. Meta-analysis reported a relative risk of 2.59 to 2.78 for preterm labor, and 2.53 to 2.86 for experiencing low birthweight when compared to general population. ${ }^{10}$ Wide resection of the paracervix may cause uterotubal innervation disorder. With the wide resection of paracervical tissue, the likelihood of spontaneous pregnancy decreases and the need for assisted reproductive methods increases. To reduce the rate of preterm labor, cervical residue should be preserved at least $1 \mathrm{~cm} .{ }^{8}$ For stage IB1 with tumor sized $>2$ $\mathrm{cm}$, the use of NAC provides higher fertility outcomes than ART only (69\% vs $49 \%$ ). Uterine artery ligation is thought to be the cause. ${ }^{14}$

\section{FOLLOW-UP}

Patients undergoing trachelectomy should be monitored every 3-4 months for the first 2 years, and then every 6 months for the next three years. ${ }^{10,12,24}$ This is based on the evidence that about $3 / 4$ of recurrences occur within 2-3 years post-treatment. However, a case of recurrence in the seventh year has also been reported, thus, annual monitoring after five years should be performed. ${ }^{12,24}$ Patients should be educated about signs and symptoms of relapse, such as abdominal and pelvic pain, lymphoedema, leg pain, haemorrhage or vaginal discharge, chronic cough, and weight loss. These symptoms are present in 46-95\% of recurrence. ${ }^{12}$ Physical examination includes inspeculo, bimanual examination, and rectovaginal palpation can help to detect most cases. ${ }^{12}$

No standard protocol has been considered as the gold standard yet. But until now cervical colposcopy and cytology are routinely used in many centers. Cytological examination is difficult, given the atypical finding in 58$60 \%$ cytology results. The image may be endometrial stromal cells, tubal metaplasia, and glandular cells of the lower uterine segment. ${ }^{10,12}$ Brown et al studied the benefits of pap smear in post trachelectomy patients from various surgical approaches. It was found that the average time required from the operation to the first abnormal result was 17.2 months, and the most common results were ASCUS (52\%), LSIL (20\%), HSIL (2\%), and AGUS (25\%). The surgical methods (ART, VRT, LRT, or RRT), trachelectomy specimen size, histologic type, and type of cervical cerclage and stenosis prevention are not predictors of Pap results. Regardless of the results obtained, no recurrence was found in 41 patients involved in the study. ${ }^{71}$ Many centers implement MRI examinations at 6, 12 , and 18 months. However, the interpretations are often difficult due to anatomical changes. ${ }^{10,12}$ PET scanning shows considerable sensitivity (86\%) and specificity $(87 \%)$, which is good in detecting recurrences. ${ }^{12}$ 
Adjuvant therapy may be considered in high-risk cases of positive or near-positive tumor margins, positive lymph nodes, and parametrial involvement. It was reported that about $10 \%$ of patients were included in this group. Stromal invasion, large tumors, and positive LVSI are moderate risk factors, and the role of adjuvant therapy can not be determined. ${ }^{10}$ Adjuvant therapy may be either chemotherapy or radiotherapy. ${ }^{10}$

\section{CONCLUSION}

The trend of younger cervical cancer patients now challenges oncoginecologists to offer adequate oncologic therapy while maintaining patients' fertility. Various treatment options such as conization, trachelectomy and neoadjuvant chemotherapy have shown satisfactory outcomes in early-stage cervical cancer. Hence, it is suggested that to every reproductive aged patient who has strong desire to maintain fertility, the options of fertility-sparing surgical therapy should always be offered and properly counselled.

\section{REFERENCES}

1. Wiebe E, Denny L, Thomas G. Cancer of the cervix uteri. International Journal of Gynecology \& Obstetrics. 2012;119(2):100-109.

2. Siegel RL, Miller KD, Jemal A. Cancer statistics, 2016. CA Cancer J Clin. 2016;66:7-30.

3. Nurcahyanti ADR. Cervical cancer: the case in Indonesia and natural product-based therapy. J Cancer Biol Res. 2016;4(1): 1078-84.

4. Shields TS, Brinton LA, Burk RD, Wang SS, Weinstein SJ, Ziegler RG, dkk. A case-control study of risk factors for inasive cervical cancer among US women exposed to oncogenic types of human papillomavirus. Cancer Epidemiol Biomarkers Prev. 2004;13(10): 1574-82.

5. Castanon A, Leung VMW, Lim AWW, Asieni P. Characteristics and screening history of women diagnosed with cervical cancer aged 20-29 years. British Journal of Cancer. 2013;109:35-41.

6. Landy R, Pesola F, Castanon A, Sassieni P. Impact of cervical screening on cervical cancer mortality: estimation using stage-specific results from a nested case-control study. British Journal of Cancer. 2016;115:1140-6.

7. Plante M. Evolution in fertility-preserving options for earlystage cervical cancer. International Journal of Gynecological Cancer. 2013;23(6):982-9.

8. Rob L, Pluta M, Skapa P, Robova H. Advances in fertilitysparing surgery for cervical cancer. Expert Rev Anticancer Ther. 2012;10(7): 1101-4.
9. Hacker NF, Vermorken JB. Cervical cancer dalam Berek \& Hacker's Gynecologic Oncology $6^{\text {th }}$ edition. Wolters Kluwer. 2015:326-389

10. Kardakis S. Fertility-preserving surgery in patients with early stage cervical carcinoma. ISRN Oncology. 2012. DOI: 10.5402/2012/817065.

11. Willows K, Lennox G, Covens A. Fertility-sparing management in cervical cancer: balancing oncologic outcomes with reproductive success. Gynecologic Oncology Research and Practice. 2016;3(9):1-1

12. Cubal AFR, Carvalho JIF, Costa MFM, Branco APT. Fertilitysparing surgery for early-stage cervical cancer. International Journal of Surgical Oncology. 2012. DOI: 10.1155/2012/93653

13. Reade CJ, Eiriksson LR, Covens A. Surgery for early stage cervical cancer: how radical should it be?. Gynecologic Oncology. 2013;131:222-230.

14. Bentivegna E, Gouy S, Maulard A, Chargari C, Leary A, Morice P. Oncological outcomes after fertility-sparing surgery for cervical cancer: a systematic review. Lancet Oncol. 2016;17:e240-53.

15. Xu L, Sun FQ, Wang ZH. Radical trachelectomy versus radical hysterectomy for the treatment of early cervical cancer: a systematic review. ACTA Obstetricia et Gynecologica. 2011;90:1200-1209.

16. Wethington L, dkk. An International Series on Abdominal Radical Trachelectomy. Int J Gynecol Cancer. 2012;22:1251-7.

17. Wamburu K, Busakhala N, Owuor K, Nyagero J. Association between stage at diagnosis and knowledge on cervical cancer among patients in a Kenyan tertiary hospital: a crosssectional study. The Pan African Medical Journal. 2016;25 (supp 2):15. DOI: 10.11604/pamj.supp.2016.25.2.10684.

18. Adegoke O, Kulasingam S, Virnig B. Cervical cancer trends in the United States: a 35-year population-based analysis. Journal of Women's Health. 2012;21(10):1031-1037.

19. Ireland Cancer Registry. Cancer in Northern Ireland 2014. 2014:1-5.

20. Schorge JO, Schaffer JI, Halvorson LM, Hoffman BL, Bradshaw KD, Cunningham FG. Williams Gynecology. The McGraw-Hill Companies. 2008:1285-1316.

21. Bai H, Cao D, Yuan F, Wang H, Xiao M Chen J, dkk. Accuracy of conization procedure for predicting pathological parameters of radical hysterectomy in stage la2-lb1 $(\leq 2 \mathrm{~cm})$ cervical cancer. Scientific Reports. 2016;6:25992. DOI: 10.1038/srep25992.

22. McLaren JF, Bates WG. Fertility preservation in women of reproductive age with cancer. 2012;12:455-511.

23. Abu-Rustum NR, Sonoda Y. Fertility-sparing surgery in earlystage cervical cancer: indications and applications. JNCCN. 2010;8(12):1435 - 1438.

24. Thomakos N, Trachana SP, Rodolakis A, Bamias A, Antsaklis $A$. Less radical surgery for fertility preservation in patients with early-stage invasive cervical cancer contemporary problematics. Gynecol Obstet. 2013;3(4). DOI: 10.4172/2161-0932.1000165. 
25. Dursun P, Dogan NU, Ayhan A. Oncofetility for gynecologic and non-gynecologic cancers: fertility sparing in young women of reproductive age. Clinical Reviews in Oncology/ Hematology. 2014;92:258-267

26. Ramirez PT, Pareja R, Rendon GJ, Millan C, Frumovitz M, Schmeler KM. Management of low-risk early-stage cervical cancer: should conization, simple trachelectomy, or simple hysterectomy replace radical surgery as the new standard of care. Gynecologic Oncology. 2014;132:254-9.

27. Al-Kalbani M, McVeigh G, Nagar H, McCluggage WG. Do FIGO stage IA and small $(\leq 2 \mathrm{~cm})$ IB1 cervical adenocarcinomas have a good prognosis and warrant less radical surgery?. International Journal of Gynecological Cancer. 2012;22(2):291-5.

28. Yamazaki H, Todo $\mathrm{Y}$, Okamoto $\mathrm{K}$, Yamashiro $\mathrm{K}$, Kato $\mathrm{H}$. Pretreatment risk factors for parametrial involvement in FIGO stage IB1 cervical cancer. J Gynecol Oncol. 2015;26(4):255-261.

29. Chandeying N, Hanprasertpong J. The prognostic impact of histological type on clinical outcomes of early-stage cervical cancer patients whom have been treated with radical surgery. Journal of Obstetrics and Gynaecology. 2017. DOI: 10.1080/01443615.2016.1245279.

30. Yasuda S, Kojima A, Maeno Y, Oki N, Miyahara Y, Sudo T, $\mathrm{dkk}$. Poor prognosiss of patients with stage Ib1 adenosquamous cell carcinoma of the uterine cervix with pelvic lymphnode metastasis. Kobe J Med Sci. 2006;52(1):9-15.

31. Hou J, Goldberg GL, Qualls CR, Kuo DYS, Forman A, Smith HO. Risk factors for poor prognosis in microinvasive adenocarcinoma of the uterine cervix (IA1 and IA2): a pooled analysis. Gynecologic Oncology. 2011;121:135-142.

32. Yule R, O'Connor D. Cone biopsy of the cervix-a new technique. Journal of Obstetrics and Gynaecology. 1962: 696-700.

33. WHO guidelines for treatment of cervical intraepithelial neoplasia 2-3 and adenocarcinoma in situ. WHO Guidelines. 2014.

34. Mathevet P, Dargent D, Roy M, Beau G. A randomized prospective study comparing three techniques of conization: cold knife, laser, and LEEP. Gynecol Oncol. 1994;54(2):175-179.

35. Xiang L, Li J, Yang W, Xu X, Wu X, Wang H. Conization using an electrosurgical knife for cervical intraepithelial neoplasia and microinvasive carcinoma. PLoS ONE. 2015;10(7):e0131790. DOI: 10.1371/journal.pone.0131790.

36. Smith AL, Frumovitz $M$, Schmeler KM, Reis R, Nick AM, Coleman RL, Ramirez PT. Conservative surgery in early-stage cervical cancer: what percentage of patients may be eligible for conization and lymphadenectomy?. Gynecol Oncol. 2010;119(2):183-6.

37. Fuh K, Blumenthal PD. Loop electrosurgical excision procedure (LEEP) in A Practical Guide to Office Gynecologic Procedures. Wolters Kluwer. 2014. DOI: 10.1111/tog.12119.

38. Yoneda JY, Braganca JF, Sarian LO, Borba PP, Conceicao CJ, Zeferino LC. Surgical treatment of micoinvasive cervical cancer, analysis of pathologic fetures with implications on radicality. International Journal of Gynecological Cancer. 2015;00:00-00.

39. Reynolds EA, Tierney K, Keeney GL, Felix JC, Weaver AL, Roman LD, Cliby WA. Analysis of outcomes of microinvasive adenocarcinoma of the uterine cervix by treatment type. Obstetrics \& Gynecology. 2010;116(5):1150-7.

40. Qian Q, Yang J, Cao D, You Y, Chen J, Shen K. Analysis of treatment modalities and prognosis on microinvasive cervical cancer: a 10-year cohort study in China. J Gynecol Oncol. 2014;25(4):293-300.

41. Bisseling KCHM, Bekkers RLM, Rome RM, Quinn MA. Treatment of microinvasive adenocarcinoma of the uterine cervix: a retrospective study and review of the literature. Gynecologic Oncology. 2007(107): 424-430.

42. Lee SW, Kim YM, Son WS, You HJ, Kim DY, Kim JH, dkk. The efficacy of conservative management after conization in patients with stage IA1 microinvasive cervical carcinoma. Acta Obstetricia et Gynecologica. 2009;88:209-215.

43. Baalbergen A, Smedts F, Helmerhorst TJM. Conservative therapy in microinvasive adenocarcinoma of the uterine cervix is justified. International Journal of Gynecologycal Cancer. 2011;21(9):1640-5.

44. Chatchotikawong U, Ruengkhachorn I, Leelaphatanadit C. Residual disease following conization with stage IA-IB1 cervical carcinoma in a high incidence region. Asian Pacific Journal of Cancer Prevention. 2014;15:7383-7.

45. Hefler LA, Polterauer S, Schneitter A, Concin N, Hostetter $\mathrm{G}$, Bentz $\mathrm{E}, \mathrm{dkk}$. Repeat surgery in patients with cervical cancer stage FIGO IA1: a series of 156 cases and a review of the literature. Anticancer Research. 2010;30:565-8.

46. Hofmeister FJ, Wolfe CW. Cold-knife conization of the cervix. Postgraduate Medicine. DOI: 10.1080/00325481. 1962.11694587.

47. Andikyan V, Khoury-Collado F, Denesopolis J, Park KJ, Hussein YR, Brown CL, dkk. Cervical conization and sentinel lymph node mapping in the treatment of stage I cervical cancer: is less enough?. Int J Gynecol Cancer. 2014;24(1):113-7.

48. Pahisa J, Alonso I, Torne A. Vaginal approaches to fertilitysparing surgery in invasive cervical cancer. Gynecologic Oncology. 2008;110:29-32.

49. Reade CJ, Eiriksson LR, Covens A. Surgery for early stage cervical cancer: how radical should it be?. Gynecologic Oncology. 2013;131:222-230.

50. Baiocchi G, Brot L, Faloppa CC, Mantoan H, Duque MR, Badiglian-Filho L, dkk. Is parametrectomy always necessary in early-stage cervical cancer?. Gynecologic Oncology. 2017. DOI: 10.1016/j.ygyno.2017.03.514.

51. Woo S, Kim HS, Chung HH, Kim SY, Kim SH, Cho JY. Early stage cervical cancer: role of magnetic resonance imaging after conization in determining residual tumor. Acta Radiol. 2015. DOI: 10.1177/0284185115620948.

52. Plante $M$, Gregoire J, Renaud MC, Sebastianelli A, Grondin K, Noel P, Roy M. Simple vaginal trachelectomy in early- 
stage low-risk cervical cancer. Int J Gynecol Cancer. 2013;23:916-922.

53. Wallwiener D, Becker S. Cervicetomy in Atlas of Gynecologic Surgery $4^{\text {th }}$ edition. Georg Thieme Verlag KG. 2014:275-282.

54. Gizzo S, Ancona E Saccardi C, Patrelli TS, Berreta R, Ais O, dkk. Radical trachelectomy: the first step of fertility preservation in young women with cervical cancer (review). Oncology Reports. 2013;30:2545-2554.

55. Halaska MJ, Robova H, Pluta M, Rob L. The role of trachelectomy in cervical cancer. Ecancer. 2015;9:506.

56. Mejia-Gomez J, Feigenber T, Arbel-Alon S, Kogan L, Benshushan A. Radical trachelectomy: a fertility-sparing option for earlly invasive cervical cancer. IMAJ. 2012;14:324-328.

57. Schneider A, Erdemoglu E, Chiantera V, Reed N, Morice P, Rodolakis A, dkk. Clinical recommendation radical trachelectomy for fertility preservation in patients with early-stage cervical cancer. Int J Gynecol Cancer. 2012;22:659-666.

58. Ramirez PT, Schmeler KM, Soliman PT, Frumovits M. Fertility preservation in patients with early cervical cancer: radical trachelectomy. Gynecologic Oncology. 2008;110:2528.

59. Abu-Rustum NR, Sonoda Y, Black D, Levine DA, Chi DS, Barakat RR. Fertility-sparing radical abdominal trachelectomy for cervical carcinoma: technique and review of the literature. Gnecologic Oncology. 2006;103:807-813.

60. Pareja R, Rendon GJ, Sanz-Lomana CM, Monzon O, Ramirez pt. Surgical, oncological, and obstetrical outcomes after adbominal radical trachelectomy - a systematic review. Gynecologic Oncology. 2013. DOI: 10.1016/j.ygyno.2013.06.010.

61. Kim JH, Park JY, Kim DY, Kim YM, Kim YT, Nam JH. Fertilitysparing laparoscopic radical trachelectomy for younng women with early stage cervical cancer. BJOG. 2010;117:3407.

62. Marterl-Billard C, Faller E, Delaine M, Boisrame T, Baldauf JJ, Akladios CY. Type B laparoscopic radical trachelectomy with pelvic lymphadenectomy for early cervical cancer. Journal of Minimally Invasive Gynecology. 2016. DOI: 10.1016/j.jmig.2016.06.004.

63. Nick AM, Frumovits MM, Soliman PT, Schmeler KM, Ramirez PT. Fertility sparing surgery for treatment of early-stage cervical cancer: open vs robotic radical trachelectomy. Gynecol Oncol.2012;124(2):276-280.
64. Li J, Wu X, Li X, Ju X. Abdominal radical trachelectomy: is it safe for IB1 cervical cancer with tumors $\geq 2 \mathrm{~cm}$ ?. Gynecologic Oncology. 2013;131:87-92.

65. Wethington SL, Sonoda Y, Park KJ, Alektiar KM, Tew WP, Chi DS, dkk. Expanding the indications for radical trachelectomy: a report on 29 patients with stage IB1 tumors measuring 2-4 centimeters. Int J Gnecol Cancer. 2013;23(6): 1092-8.

66. Lintner B, Saso S, Tarnai L, Novak Z, Palfalvi L, Del Priore G, dkk. Use of abdominal radical trachelectomy to treat cervical cancer greater than $2 \mathrm{~cm}$ in diameter. Int J Gynecol Cancer. 2013;23(6):1065-1070.

67. Pareja R, Rendon GJ, Vasquez M, Echeverri L, Sanz-Lomana $\mathrm{CM}$, Ramirez PT. Immidiate radical trachelectomy versus neoadjuvant chemotherapy followed by conservative surgery for patients with stage IB1 cervical cancer with tumors $2 \mathrm{~cm}$ or larger: a literature review and analysis of oncological and obstetrical outcomes. Gynecologic Oncology. 2015;137:574-580.

68. Marchiole P, Tigaud JD, Costantini S, mammoliti S, Buenrd A, Moran E, Mathevet P. Neoadjuvant chemotherapy and vaginal radical trachelectomy for fertility-sparing treatment in women affected by cervical cancer (FIGO stage IB-IIA1). Gynecologic Oncology. 2011;122:484-490.

69. Feng $\mathrm{Y}$, Cao $\mathrm{T}$, Wang $\mathrm{Y}$, Huang $\mathrm{H}$, Xie $\mathrm{Y}$, Liu J. Neoadjuvant chemothherapy followed by conization to spare fertility in cases of locally advanced cervical cancer: a case report and review of the literature. Molecular and Clinical Oncology. 2016;5:411-6.

70. Salihi R, Leunen K, Limbergen EV, Moerman P, Neven P, Vergote I. Neoadjuvant chemotherapy followed by large cone resection as fertility-sparing therapy in stage IB cervical cancer. Gynecologic Oncology. 2015. DOI: 10.1016/j.ygyno.2015.05.043.

71. Brown AJ, Shah JS, Fleming ND, Nick AM, Soliman PT, Chisholm GB, dkk. Role of cervical cytology in surveillance after radical trachelectomy for cervical cancer. Gynecologic Oncology. 2016. DOI: 10.1016/j.ygyno.2016.05.030. 